\title{
Analysis of nosocomial outbreak caused by contamined liquid hand soaps: A single-center study
}

\section{Kontamine sıvı el sabunlarına bağlı hastane enfeksiyonu salgını analizi: Tek merkezli bir çalıșma}

\author{
Rezan HARMAN ${ }^{1}$, Mehmet DOKUR ${ }^{2}$
}

\begin{abstract}
Objective: $P$. aeruginosa and Klebsiella spp. are the most common gram negative pathogens seen in the etiology of hospital acquired infection outbreaks. Inadequate hygiene and contaminated liquid hand soaps have important roles in the spread of bacteria. In this study, we identified the source and causes of nosocomial infection outbreak in a tertiary hospital.
\end{abstract}

Methods: CCulture samples were randomly obtained from soap dispensers filled with anionic liquid hand soap without antiseptic during the outbreak and from dispensers containing disposable liquid hand soap with antiseptic within the 5 years after the outbreak. The samples were cultivated in eosin methylene blue agar and blood agar mediums. In the identification of obtained samples, VITEK® 2 Compact automated system (bioMérieux, Marcy l'Etoile, France) was used.

Results: Among culture samples obtained from 18 patients with coronary by-pass during nosocomial outbreak in our hospital in 2011, P. aeruginosa $(n=17)$ and Klebsiella spp. $(\mathrm{n}=8)$ were isoled. . In culture samples of type A liquid hand soap group (anionic, antiseptic-free), $P$. aeruginosa $(\mathrm{n}=58)$ and Klebsiella spp. $(n=15)$ were isolatedduring nosocomial infection

\section{ÖZET}

Amaç: $P$. aeruginosa ve Klebsiella spp. hastane enfeksiyonuna neden olan patojenik gram-negatif bakterilerden en sık karșılașılan iki çeșididir. Yetersiz hijyen ve bakteri ile kontamine olmuş sıvı el sabunları, söz konusu bakterilerin yayılmasında öne çıkan iki faktördür. Bu çalıșmada üçüncü seviye bakım yapan bir hastanede hastane enfeksiyonu salgınının neden ve kaynakların belirledik.

Yöntem: Salgın esnasında antiseptik içermeyen anyonik sıvı sabun ile doldurulmuş sıvı sabunluklardan ve salgından sonraki beș yılda antiseptik sıvı sabun ile doldurulmuș sıvı sabunluklardan rastgele kültür örnekleri alınmıștır. Alınan örnekler eozin metilen mavi agar ve kanlı agar besiyerlerine ekildi ve elde edilen bakteri izolatlarının tanımlaması VITEK $® 2$ Compact otomatize sistemi (bioMérieux, Marcy l'Etoile, Fransa) kullanılarak gerçekleștirildi.

Bulgular: Hastanemizde 2011 yılında meydana gelen bir hastane enfeksiyonu salgını sırasında 18 koroner bypass hastasından alınan kültür örneklerinde $P$. aeruginosa $(\mathrm{n}=17)$ ve Klebsiella spp. $(\mathrm{n}=8)$ izole edilmiștir. A tipi sıvı el sabununun (anyonik, antiseptik içermeyen) kültür örneklerinde salgın boyunca ve dezenfeksiyon sonrası

'Sanko University Hospital, Department of Infectious Diseases, Gaziantep

${ }^{2}$ Biruni University Medical Faculty, Department of Emergency Medicine, Istanbul

Illetişim / Corresponding Author : Rezan HARMAN

DOI ID : 10.5505/TurkHijyen.2018.69862

Harman R, Dokur M. Analysis of nosocomial outbreak caused by contamined liquid hand soaps: A single-center study. Turk Hij Den Biyol Derg, 2019; 76(3): 267-274 
outbreak and in the early periods after disinfection. No further nosocomial outbreak infections were detected during the next 5-year period after use of Soap type B (antiseptic foam soap) and Soap type C (disposable antiseptic liquid soap). A few number of pathogens including $P$. aeruginosa $(\mathrm{n}=1)$ and Klebsiella spp. $(\mathrm{n}=2)$ were isolated in culture samples obtained from Soap type $B$ dispensers. No bacteria were isolated in samples obtained from Soap type $\mathrm{C}$ dispensers.

Conclusion: The use of disposable liquid hand soap with antiseptic prohibits contamination and consequently, prevents nosocomial infection outbreaks.

Key Words: Liquid hand soaps, disposable, contamination, nosocomial outbreak erken dönemlerde $P$. aeruginosa $(n=58)$ ve Klebsiella spp. ( $n=15)$ izole edilmistir. Salgın sonrasındaki beș yıllık süreçte B (antiseptikli köpük sabun) ve C (antiseptikli sıvı sabun) tipi sabun kullanımlarında herhangi bir hastane salgınına rastlanmadı. Sadece B tipi sabunluklardan alınan örneklerde eser miktarda $P$. aeruginosa $(n=1)$ ve Klebsiella spp. ( $\mathrm{n}=2)$ gözlenmiștir. C tipi sabunluklardan alınan örneklerde herhangi bir bakteriye rastlanmadı.

Sonuç: Antiseptik içeren tek kullanımlık sıvı el sabunu kullanımı, bulașmayı engelleyerek hastane enfeksiyonu salgınını önler.

Anahtar Kelimeler: Sıvı el sabunları, tek kullanımlık, bulaş, hastane enfeksiyonu salgını

\section{INTRODUCTION}

Hospital outbreaks are important clinical issues that occur from time to time in hospitals' Intensive Care Units (ICU) and it can lead to mortal and morbid for risky patients and also healthcare providers. ICU of hospitals have suitable conditions for $P$. aeruginosa to live and reproduce. Other gramnegative bacteria strains (Klebsiella spp.,etc.) may also cause nosocomial infections $(1,2)$. Hand hygiene is the most effective factor in preventing hospital infections and also interrupting faecalhand contamination by washing (3). Soaps clean the dirt, organic matters and pathogenic bacteria on hands with their detergent feature. Some agents generally affects by killing bacteria on flora, even though they have minimal differences between each other (4). This study focuses on the examination of processes and solutions we followed on the verge of determining bacterial isolation in the soap samples collected to conduct a research on a nosocomial outbreak occurred in Cardiovascular Surgical ICU of
Sanko University Hospital in 2011.

\section{MATERIAL and METHOD}

\section{Introducing setting}

Sanko University Hospital is a third level health care institution with 600 patient beds capacity. We have four ICUs (general ICU, Cardiovascular Surgical ICU, neonatal ICU and coronary ICU) in our hospital. Number of patients admitted in ICU's are around 9000 per year.Alcohol-based soaps were widely used before the outbreak in 2011. Liquid hand soap dispensers group subject to our study that were used before the outbreak consisted of 476 liquid soap dispensers in all of the clinics of our hospital and they were filled with standard liquid hand soap commonly used in hospitals, manufactured only by the same company with a single type chemical formula including sodium hydroxide $(\mathrm{NaOH})$ (anioactive type) and without disinfectants (Soap 
A). After the hospital outbreak, wall mounted soap dispensers filled with amphoteric, eco-labeled, liquid foam hand soap with betaine were preferred (Soap B). Another soap type (Soap C) was similar to Soap B with chemical formulation but it was used only in operating rooms, ICUs, laboratories and sterilization units.

\section{Patients characteristics}

We found total number of patients with nosocomial infections was 18 and $11(61 \%)$ of the patients were female and 7 (39\%) were male (Mean: $68.8 \pm 10.5$ years (range:42-81). Mean of length of stay in hospital was $18.1 \pm 4.1$ days (range:7-22). Meanwhile, total number of patients underwent coronary bypass surgery was 61 in the month of nosocomial outbreak. (Number of patients who underwent coronary by pass surgery was 221 in 2011). Furthermore the most frequent underlying diseases were hypertension and diabetes mellitus; number of patients were $7(38 \%)$ and $6(33 \%)$ respectively. (Table 1).

\section{Collection of samples and Bacterial isolates}

\section{Liquid hand soap isolates}

Within the scope of activities of Infection Control Committee (ICT), environmental cultures were collected from Cardiovascular Surgical Service and ICU to conduct a research on the outbreak. Consequently $P$. aeruginosa and Klebsiella spp. reproduction in the liquid soap culture samples, new cultures were randomly collected from a total of 52 liquid hand soap dispensers in the hospital, especially in the risky areas. Thus, a more accurate bacterial culture sampling was obtained in this study.

\section{Clinical isolates}

Bacterial culture samples were obtained from liquid soap dispensers in our hospital by members

Table 1. Characteristics of patients with nosocomial infection $(\mathrm{N}=18)^{*}$

Parameters

Age

18-65 years

$\geq 65$ years

Mean: $68.8 \pm 10.5$ years (range:42-81)

Gender

Male

Female

Underlying disease

Diabetes Mellitus Type 2

Chronic obstructive pulmonary disease

Chronic renal failure

Hypertension

Length of stay in hospital

$\begin{array}{lr}5-15 \text { days } & 4 \\ \geq 15 \text { days } & 14\end{array}$

Mean:18.1 \pm 4.1 days (range:7-22)

Total

Number of patients

Percent (\%)

3

15

7

11

6

2

3

7

4

14

18
20

80

39

61

33

11

17

39

22

78

100

\footnotetext{
${ }^{*}$ Total the number of patients underwent coronary bypass surgery was 61 in the month of nosocomial outbreak and also the number of patients who underwent coronary by pass surgery was 221 in 2011.
} 
of ICT. Then these samples were inoculated in eosin-methylene-blue and blood agar plates. The inoculated plates were then incubated aerobically at $37^{\circ} \mathrm{C}$ for 24 hours.

\section{Bacterial identification and antibiotic susceptibility testing}

Identification and antibiotic susceptibility tests on the bacteria isolated from cultures were completed by using VITEC $2 ®$ compact automated system (bioMérieux Industry, France). Antibiotic susceptibility tests were performed to detect antibiotic resistance of the bacterial isolates.

\section{Ethical status}

The research was conducted in full accord with the tenets of World Medical Association Declaration of Helsinki (ethical principles for medical research involving human subjects).

\section{RESULTS}

In this study, among the patients underwent coronary by-pass in our hospital's Cardiovascular Surgical ICU and inpatient clinic during nosocomial outbreak, 18 patients were diagnosed with surgical wound infection; Klebsiella spp. was 6 (33\%) and P. aeruginosa was also 12 (67\%). 7 patients were diagnosed with blood culture infection; Klebsiella spp. was 2 (29\%) and P. aeruginosa was 5 (71\%). Thus, total number of bacterial isolate was 25 . (Table 2).
Bacterial culture samples $(n=52)$ were obtained from liquid hand soap dispensers (Soap A) in Cardiovascular Surgical ICU of our hospital during nosocomial outbreak. The distributions of bacterial culture results were as follows: $P$. aeruginosa was 15 (29\%) and of Klebsiella spp. was 34 (65\%), and also in $3(6 \%)$ bacterial culture samples there was no isolation. (Table 3)

After this, new bacterial culture samples were obtained from the soap barrel (primary soap distribution source). But, no bacterial isolation was detected. All contaminated liquid hand soaps dispensers were disinfected with $2 \%$ glutaraldehyde and refilled with Soap A by ICT of Sanko University Hospital. New culture samples were collected from contact points with external environment and the interior parts of the same liquid hand soap dispensers $15(60 \%)$. in the total 25 bacterial culture isolates were $P$. aeruginosa and $0(0 \%)$ were Klebsiella spp. and also in 10 (40\%) bacterial culture samples there was no isolation after 2 days the first disinfection (Table 3).

Liquid hand soap dispensers were again collected and disinfected in the same way and refilled with Soap A. Two days after second disenfection, new culture samples were obtained from contact points with external environment of liquid hand soap dispensers. The number of isolated $P$. aeruginasa was $9(36 \%)$ and $0(0 \%)$ were Klebsiella spp. and also in 16 (64\%) bacterial culture samples there was no isolation in total 25 bacterial culture samples.

Table 2. Liquid hand soap isolates and bacterial culture results (during nosocomial outbreak)

\begin{tabular}{lccc} 
Isolate sources & Number of isolate & \multicolumn{2}{c}{ Bacterial culture results } \\
Wound/Pus culture & 18 & Klebsiella spp. | P.aeruginosa \\
Blood culture & 7 & $6(33 \%)$ & $12(67 \%)$ \\
Total & 25 & $2(29 \%)$ & $5(71 \%)$ \\
\end{tabular}


Table 3. Distribution of bacterial culture results obtained from liquid hand soap dispenser during and after outbreaks (20112016)

\section{Surveillance}

During the nosocomial outbreak

After two days first disenfection

After two days second disenfection

1 year after the initial outbreak

2 years after the initial outbreak

3 years after the initial outbreak

4 years after the initial outbreak

5 years afters the initial outbreak

1 year after the initial outbreak

2 years after the initial outbreak

3 years after the initial outbreak

4 years after the initial outbreak

5 years afters the initial outbreak
Bacterial culture results

Soap | Klebsiella spp.|P. aeruginosa |No reproduction | Total

$\begin{array}{lllll}\text { A } & 15(29 \%) & 34(65 \%) & 3(6 \%) & 52 \\ \text { A } & 0(0 \%) & 15(60 \%) & 10(40 \%) & 25 \\ \text { A } & 0(0 \%) & 9(36 \%) & 16(64 \%) & 25 \\ \text { B } & 0(0 \%) & 0(0 \%) & 23(100 \%) & 23 \\ \text { B } & 1(5 \%) & 0(0 \%) & 19(95 \%) & 20 \\ \text { B } & 0(0 \%) & 0(0 \%) & 22(100 \%) & 22 \\ \text { B } & 1(3.8 \%) & 1(3.8 \%) & 24(92.4 \%) & 26 \\ \text { B } & 0(0 \%) & 0(0 \%) & 26(100 \%) & 26 \\ \text { C } & 0(0 \%) & 0(0 \%) & 0(0 \%) & 0 \\ \text { C } & 0(0 \%) & 0(0 \%) & 0(0 \%) & 0 \\ \text { C } & 0(0 \%) & 0(0 \%) & 0(0 \%) & 0 \\ \text { C } & 0(0 \%) & 0(0 \%) & 0(0 \%) & 0 \\ \text { C } & 0(0 \%) & 0(0 \%) & 0(0 \%) & 0\end{array}$

Same bacterial isolates were also determined in the bacterial cultures obtained from the interior parts of the same liquid soap dispensers containing Soap A (Table 3).

Liquid hand soap dispensers were again collected and disinfected in the same way and refilled with liquid hand soap dispensers containing foam soap with antiseptic and eco-labeled (Soap B) to prevent contamination. After Soap B, almost no bacterial isolation was detected during the 5-year period (Table 3).

In order to get a better result, we went to a step further and tried to use another soap type (Soap C). Soap $C$ had similar chemical formulation with Soap B, but it was completely disposable and it was used in operating rooms, ICUs, laboratories and sterilization units.

A total of 164 bacterial culture samples were obtained from new liquid hand soap dispensers after the use of Soap B and Soap C (total number of sample were 124 and 40 respectively) during the 5 -years-long surveillance period. The number of total bacterial isolates was 117 after this period. But, the number of bacterial isolates obtained from Soap B dispensers was only 3. (Klebsialla spp., $\mathrm{n}=2$ and $P$. aeruginosa, $\mathrm{n}=1$ ). Unlike not any bacterial isolation in soap cultures were obtained from Soap $C$ dispensers. Therefore, no new outbreak caused by Soap B and Soap C was determined in our hospital during the 5-years-long surveillance period (Table 3).

\section{DISCUSSION}

It is widely known that soaps can colonize with gram-negative microorganisms during nosocomial outbreaks. $P$. aeruginosa and Klebsiella spp. are two 
of the most commonly colonizing microorganisms $(5,6)$. It is important to always keep in mind that these microorganisms, that are also an important factor in hospital outbreaks, can easily colonize in soaps and disinfectants and cause infections (7). In order to prevent such infections, all soap dispensers, washed thoroughly and dried by draining, and new soap dispensers mounted during this process. However, it should be taken into consideration that this process does not work as expected due to lack of attention of medical staff.

In an etiologic study conducted by Blanc et al. (8), as pathogenic bacteria $P$. aeruginosa $(n=776)$ was isolated from 358 patients out of 382 patients with nosocomial infection $(93.7 \%)$ treated in a tertiary care university hospital. We detemined that only $3(0.8 \%)$ of the patients with nosocomial infection were due to contaminated liquid hand soaps. In the findings Blanc et al. concluded, it is especially remarkable that the most frequent contamination element in nosocomial infections is $P$. aeruginosa even though the most frequent contamination route is not soap dispensers. The findings of our study about the most common isolate being $P$. aeruginosa matches with the study Blanc et al.

Although the importance of hand washing is considered an important factor in the prevention of nosocomial infections, there is always a resistance to it. This resistance was tried to be balanced with disinfectants.

The accessibility of hand disinfectants the ease of use with a very little amount of time required increased the adaptation to hand hygiene. Intense and increased work-loads may affect nurses negatively in following the rules about hygiene (9). Consequently, latest guides suggest utilization of hand disinfectants as long as there isn't any visible dirt on hands or a contamination with sporophyte microorganisms (10). Conformity with hand hygiene does not surpass 50\% in many hospitals. Hospital infection rate around the globe is around $7-10 \%$ and the treatments of these infections are quite costly. In $20-40 \%$ of the cases of carrying and spreading microorganisms that shows high virulence and multiple treatment resistance between patients are caused by dirty hands of healthcare personnel. At least $50 \%$ of this problem could simply be solved with hand $(3,4)$. Effectiveness of washing hands depends on length and technique. Length usually needs to be short in hospitals due to work load. Effective washing length is generally 8 to 20 seconds. However, when we add before and after procedures such as going to the washbasin and coming back, this period increases to 40 to 80 seconds. One minute-long hand washing session causes a significant decrease in microorganism number $(11,12)$. Hands must be rinsed well after washing, dried with singleuse paper towel and the sink must be turned off with paper towel or knee. A lotion must be used to protect hands after washing (3).

In order to increase the adaptation of patients and healthcare professionals to hygienic rules, it is important to have adequate number of wash-hand basins in the work area, with sinks that can be easily controlled with knees or arms, and provide easy access to liquid hand soap, lotion and paper towels. Containers used to refill liquid soaps must be cleaned and disinfected; preferably, hand soaps contained in soft, disposable containers that does not create a negative pressure during pumping must be used. In order to reduce the risk of contamination, liquid hand soap dispenser, which can be controllable by the elbows, is preferred. $(2,3,13,14)$. It is noteworthy that after the use of Soap B and Soap C, there is no nosocomial outbreak in inpatient clinics of our university hospital.

\section{CONCLUSION}

Disposable liquid hand soap completely prevents contamination. This can be an effective solution to the prevention of nosocomial infections. Hence, along with hygiene precautions disposable liquid hand soap dispensers must be used especially in risky areas 
such as operating rooms, ICUs, hematology/oncology units, burn units, disinfection and sterilization units and labs, and in all units of hospitals if possible.

\section{ACKNOWLEDGMENT}

We thank members of ICT and technical staff of Sanko University Hospital for assistance.

\section{REFERENCES}

1. Gaynes R, Edwards JR. Overview of nosocomial infections caused by gram-negative bacilli (National Nosocomial Infections Surveillance System).Clin Infect Dis 2005;41: 848-54.

2. Tyczkowska-Sieron R, Bartoszko-Tyczkowska A, Gaszynski W. Bacterial infections in Intensive Care Unit patients analyzed on the example of the Lodz Medical University Hospital No 1 in the period 20022015. Med Dosw Mikrobiol 2016;68:39-46.

3. Boyce JM, Pittet D. Guideline for Hand Hygiene in Health-Care Settings: recommendations of the Healthcare Infection Control Practices Advisory Committee and the HICPAC/SHEA/APIC/IDSA Hand Hygiene Task Force. Healthcare Infection Control Practices Advisory Committee. Society for Healthcare Epidemiology of America. Association for Professionals in Infection Control. Infectious Diseases Society of America. Hand Hygiene Task Force. Infect Control Hosp Epidemiol 2002;23(12 Suppl):S3-40.

4. Esen S. Hand hygiene and antiseptics. In Gunaydin $M$, Sunbul $M$, editors. National Sterilization and Disinfection Congress Book. Ankara, 2003: SIMAD press. 120-30.

5. Geadas Farias P, Gama F, Reis D, Alarico S, Empadinhas N, Martins JC, et al. Hospital microbial surface colonization revealed during monitoring of Klebsiella spp., Pseudomonas aeruginosa, and non-tuberculous mycobacteria. Antonie Van Leeuwenhoek 2017;110:863-76.
6. Fanci R, Bartolozzi B, Sergi S, Casalone E, Pecile P, Cecconi D, et al. Molecular epidemiological investigation of an outbreak of Pseudomonas aeruginosa infection in an SCT unit. Bone Marrow Transplant 2009;43:335-8.

7. Lanini S, D’Arezzo S, Puro V, Martini L, Imperi F, Piselli P, et al. Molecular epidemiology of a Pseudomonas aeruginosa hospital outbreak driven by a contaminated disinfectant-soap dispenser. PLoS One 2011; 6:e17064.

8. Blanc DS, Gomes Magalhaes B, Abdelbary M, Prod'hom G, Greub G, Wasserfallen JB, et al. Hand soap contamination by Pseudomonas aeruginosa in a tertiary care hospital: no evidence of impact on patients. J Hosp Infect 2016; 93:63-7.

9. Scheithauer S, Batzer B, Dangel M, Passweg J, Widmer A. Workload even affects hand hygiene in a highly trained and well-staffed setting: a prospective 365/7/24 observational study. J Hosp Infect 2017;97:11-6.

10. Ataee RA, Ataee MH, Mehrabi Tavana A, Salesi M. Bacteriological Aspects of Hand Washing: A Key for Health Promotion and Infections Control. Int J Prev Med 2017; 8:16.

11. de Vries JH, van Dorp WT, van Barneveld PW. A randomized trial of alcohol $70 \%$ versus alcoholic iodine $2 \%$ in skin disinfection before insertion of peripheral infusion catheters. J.Hosp. Infect 1997;36:317-20. 
12. Boyce JM. Using alcohol for hand antisepsis: Dispelling old myths. Infect Control Hosp Epidemiol 2000; 21:438-41.

13. Marino C, Cohen M. Washington state hospital survey 2000: gloves, hand washing agents and moisturizers. Am J Infect Control 2001; 29: 422-4.
14. Healthcare Infection Control Practices Advisory Committee and Hand-Hygiene Task Force; Society for Healthcare Epidemiology of America; Association for Professionals in Infection Control and Epidemiology; Infection Diseases Society of America Guideline for hand hygiene in healthcare settings. J Am Coll Surg 2004; 198:121-7. 